\title{
Gold in the Search for the Americas
}

\author{
J. R. Fisher \\ Department of Modern History, University of Liverpool, England
}

Gold is a metal most excellent above all others and of gold treasures are formed, and he who has it makes and accomplishes whatever he wishes in the world and finally uses it to send souls into Paradise.

The meaning of these words of Christopher Columbus hardly requires explanation, notwithstanding his rather obscure reference to religion. Although the Genoese discoverer was motivated to some degree, like the thousands of men who were to follow him to the New World in the century after 1492, by the desire to carry Christianity to the heathen, his primary purpose was to seek the precious metal with which a man could accomplish whatever he wished.

Long before Columbus began to formulate his idea that the legendary Cipangu (Japan) and Cathay (China) of the Venetian traveller Marco Polo might be reached by sailing west across the Atlantic, Portuguese explorers, inspired by Prince Henry the Navigator between 1419 and 1460, had been probing down the African coast in search of a sea-route to Asia. As early as 1442, with the settlement of the Azores, Madeira, and the Cape Verde Islands already behind them, these skilful navigators were able to bring back from West Africa Touareg gold obtained by barter. It is not known how much gold reached Lisbon in the years which followed, but the volume was sufficient to enable the mint to resume issue in 1457 of a fine gold coin, the cruzado; in the first half of the century Portugal had been one of the few states in Europe without a gold currency.

After the capture of Constantinople by the Turks in 1453 the traditional Levantine trade route which

\footnotetext{
Among the complex motives that inspired Columbus in his long endeavours to secure financial support for his proposed royage to "The Indies" the prospect of finding gold was prominent. When King Ferdinand and Queen Isabella of Spain finally agreed to sponsor the expedition in 1492 they provided him with a Book of Privileges setting out his titles as Admiral of the Ocean Sea and Viceroy and Governor of the lands to be discovered and according him one-tenth of the hoped-for gold and other treasure

Courtesy of the Naval Museum, Genoa
}

supplied Europe with Asian silks, spices and gold, together with some Sudanese gold, became more uncertain and the quest for an alternative avenue to the east became even more urgent, despite the fact that the shortage of bullion was alleviated by Portugal's West African supplies and by the revival of silver mining in Germany after 1470. Convinced that their African route was the true one, the Portuguese turned down Columbus' proposals when he first went to Lisbon in 1484. But Isabella of Castile, after a long delay, reacted more positively. It was thus on behalf of Castile that Columbus set out westward on August 3rd, 1492, armed with a letter of introduction to the Great Khan and a patent granting him, among many other privileges, one-tenth of the profits from all the precious metals and stones that he might acquire.

This first voyage took Columbus to the Bahamas, Cuba, and Hispaniola (modern Haiti). Although he was to continue to insist until his death in 1506 that the lands he had found lay off the coast of Asia-

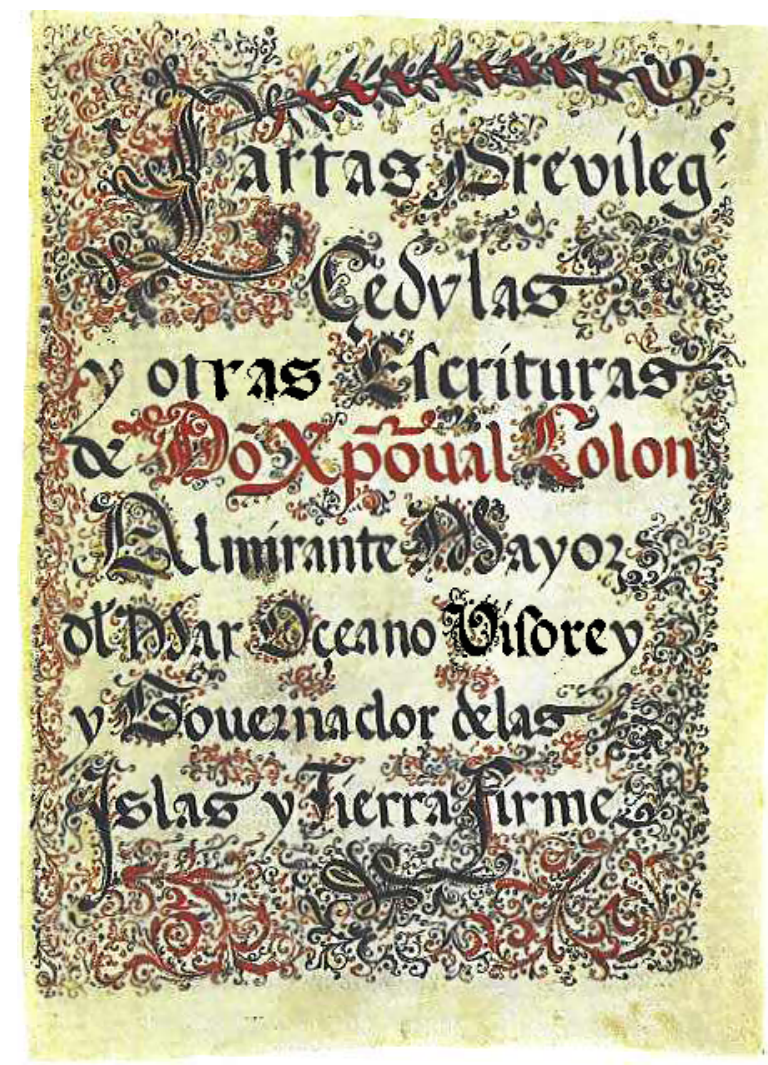


Melting gold in Central America in the sixteenth century. A Franciscan Friar, Bernardino de Sahagún, lived for many years among the natives and eneouraged them to describe their ways of life and the story of the Spanish conquest, setting it down in the language of the Mexican valley with a Spanish translation and illustrating his work, The General History of the Things of New Spain, completed in 13 volumes in about 1565, with a great number of miniatures such as this. The use of the blow pipe and of a pottery crucible on short feet corresponds with a later description by Sir Walter Raleigh of "a great earthen potte with holes round about it, and when they had mingled the gold and copper together, they fastened canes to the holes, and so with the breath of men they increased the fire till the mettell ran, then they cast it into moulds of stone and elay"

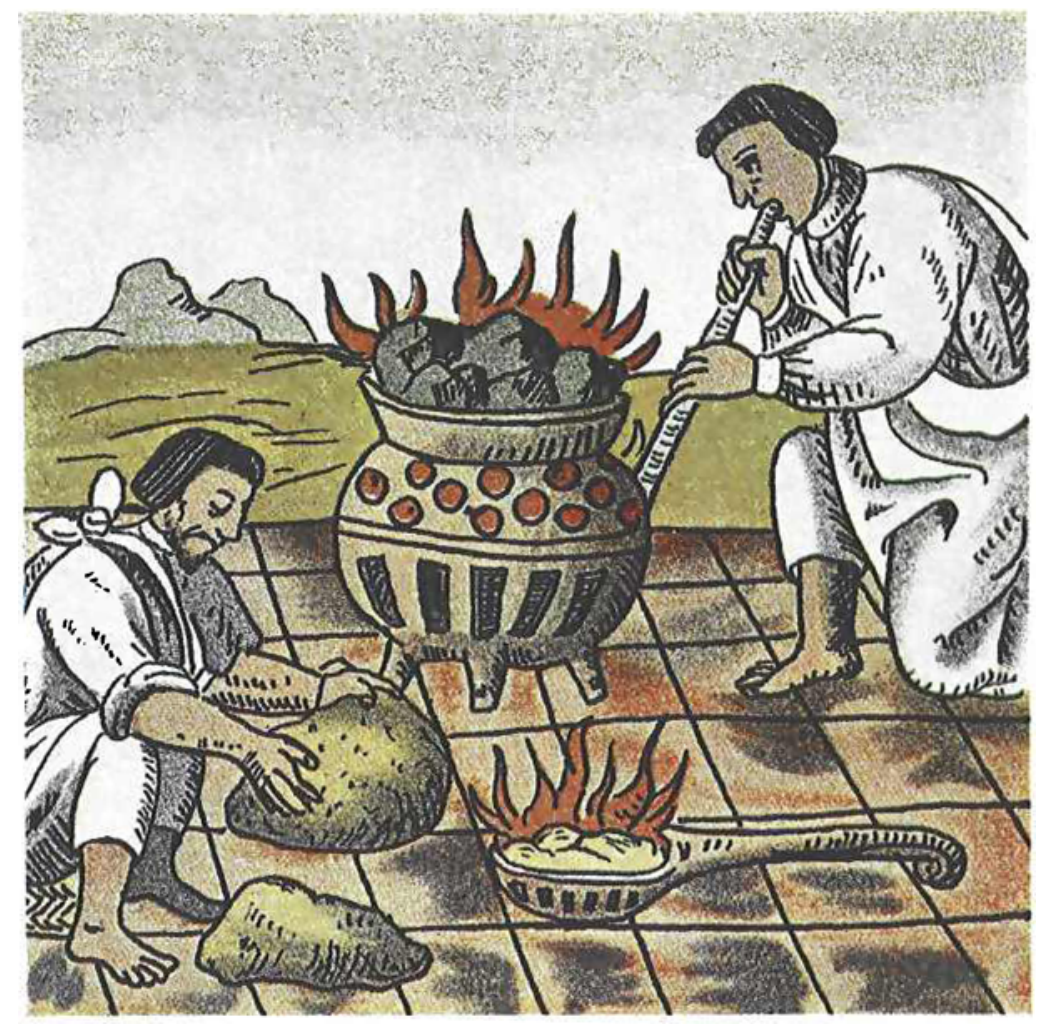

despite Amerigo Vespucci's demonstration that, in fact, they lay off a new continent-the journal that he kept makes it abundantly clear that, following his landfall in the Bahamas on October 13th, the Great Khan was virtually forgotten as the search for gold became paramount. His entry for that very day, describing his first encounter with the natives, tells us:

"And I was attentive and sought to learn whether they had gold and I saw that some of them wore a small piece suspended from a hole they have in the nose: and I was able to understand by signs that, going to the south .. , there was a King who had large vessels of gold and who had a great deal of it."

The Asian mainland, Columbus believed, lay further to the west, but, following receipt of this information, he "resolved to go to the south-west, to seek the gold and precious stones". The island of Cuba, which he found by taking this new course, proved, in fact, to be something of a disappointment, but prospects brightened on the north coast of Hispaniola. There the explorers not only obtained gold nose-plugs and bracelets from the natives but also discovered a river which yielded sand "all full of gold, to such an extent that it was a marvel, although very small". Some grains, however, were "as large as lentils", and Columbus predictably named the source of this wealth Río del Oro, River of Gold.

Following further discoveries of placer gold by a party sent to the interior of Hispaniola, Columbus set out for home to inform Ferdinand and Isabella, the Spanish sovereigns, of his and their good fortune.
The key sentence in his first letter to them is the following:

"In this Española . . is the best district for the gold mines and for all the trade both with this continent and with that over there belonging to the Great Khan, where there will be great trade and profit."

His reference to "mines" was strictly inaccurate, for it appears that all pre-Columbian gold throughout the Americas was obtained from placer deposits, but the gold objects which he was able to display persuaded the crown that Hispaniola could rapidly be turned into a self-sufficient, gold-producing colony. By September 1493, only six months after his return, Columbus was ready to set out again with no less than twelve hundred settlers, including not only artisans and farmers but also miners.

For the next two decades the Spanish conquistadors rampaged through the Antilles in their search for gold. The crown made half-hearted attempts to protect the native population by encouraging the emigration of peasant families who might devote themselves to agriculture, but without notable success. The reason was aptly summed up by Hernan Cortés' reply to an official who offered him land when he reached Hispaniola in 1504: "But I came to get gold", declared the future conqueror of Mexico, "not to till the soil like a peasant".

Within three decades of the island's discovery the exploitation and abuse of the native population which this quest involved had wrought a demo- 


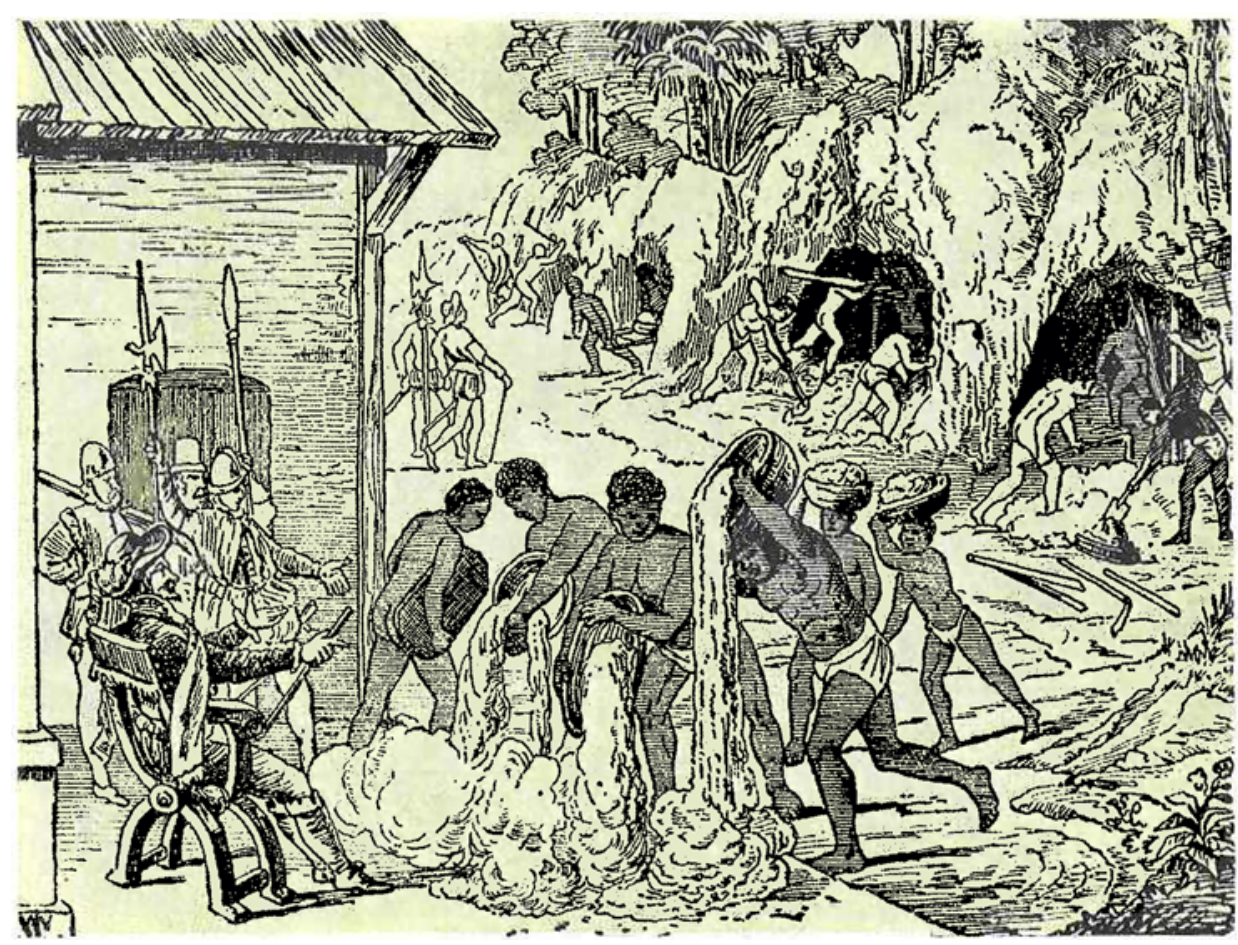

This rather imaginative representation, by the sixteenth century Flemish author and engraver Theodor de Bry, shows Indians busily mining gold in Hispaniola and bringing their output to a group of Spanish soldiers. In fact the gold in the newly discovered Americas was virtually all obtained from alluvial deposits in the river beds

graphic catastrophe which, in its turn, stifled economic activity until Negro slaves began to be introduced in large numbers in the second half of the sixteenth century. In an attempt to redress the consequential decline in gold production the Emperor Charles V arranged in 1529 for the Welser Company of Augsburg to send eighty Silesian miners to Hispaniola. Although this particular venture appears to have ended in failure, with heavy mortality among the miners, it is significant as the first known attempt to exploit the expertise of German miners in the Americas. As Georgius Agricola's famous work, De Re Metallica (1556) proudly illustrates, the Germans had been in the forefront of the recovery of European gold mining in Bohemia and Silesia in the fourteenth and fifteenth centuries. The great Augsburg banking families of the Welsers, Fuggers, and Höchstetters, moreover, had been prominent for many years in the mining of silver and base metals in various parts of southern and eastern Germany, partly as a result of a tendency to accept mining concessions as security for loans. In attempting to exploit their experience in both mining and trade, therefore-German involvement in overseas economic activity as a whole was at a height in 1524 to 38-Charles $V$ was both showing good sense and, as we shall see, setting a precedent which Elizabeth I of England and her ministers were to take note of later in the century.
The Spanish quest for gold in the New World was facilitated by the fact that the metal had no monetary value for the natives. Even in Inca Peru, where its affinity with the sun-gold was "the sweat of the sun" - gave it a religious significance, it was not used for trade. The mutual incredulity of Spaniards and natives at their respective attitudes towards gold is captured by Peter Martyr's account of Columbus' second voyage, published in 1530 . He tells us:

"One old man only asked a little bell in return for two grains of gold weighing an ounce. Seeing that the Spaniards admired the size of these grains, and quite amazed at their astonishment, he explained to them by signs that they were of no value ... It is now known that the islanders set no value on gold as such; they only prize it when it has been worked by a craftsman into some form which pleases them."

For the Spaniard, however, as for virtually all Europeans in the sixteenth century, gold objects, no matter how beautiful, had no aesthetic significance. Gold represented power: power for the adventurer to return home to a life of luxury, power for the monarch-from 1504 the Spanish sovereign took a fifth, or "quint", of all American treasure for hiniself - to wage an ambitious foreign policy. When Albrecht Dürer saw the treasure of the Aztec emperor Montezuma on display in Brussels in 1520 he judged it to be "more beautiful than the things of which miracles are made". Every single piece, however, was melted down. 
It is possible to relate fluctuations in the remittances of treasure from the New World to Spain to the various stages of the Spanish conquest. Shipments reached an early peak in 1511-15, following the penetration of Panama and Costa Rica, where the natives had for many centuries been producing pendants by the method of lost-wax casting. The conquest of Mexico in 1519-21 provided a further boost, as a vast quantity of accumulated gold objects fell into the hands of Cortés and his men.

A decade later the conquest of Peru by Francisco Pizarro brought the third great gold-producing area of ancient America firmly under Spanish control. Native craftsmen there had been working gold for at least two thousand years, and were masters of advanced hollow-core casting and of decorative techniques involving the use of soldering.

Most of the gold objects which the Spaniards found in Peru were, in fact, not strictly "Inca", but the products of earlier civilisations, such as the Chimú, which had recently been absorbed into the empire ruled from Cuzco. Whereas most early Mexican goldware did not survive the conquest, a considerable number of Peruvian pieces did escape because they remained hidden in desert burial sites until this century. Those items which did fall into the hands of Pizarro and his followers, no matter how beautiful, were simply melted down: they included the gold litter of the Inca emperor, Atahualpa, and the lifesize gold and silver animals and plants of the sacred garden of the sun-god in Cuzco. The looting of the gold of Peru by Pizarro was facilitated by the vain attempt of Atahualpa to purchase his freedom by offering to fill a certain room with gold and twice over with silver.

The melting down of this ransom on nine forges continued for four months in 1533 and produced for Pizarro's 168 men no less than 13,420 pounds of
221 carat gold and 26,000 pounds of good silver. Even the simple foot soldiers each received forty-five pounds of gold and ninety of silver. Many retired immediately to Spain to spend the rest of their lives in luxury, and, by their example, to encourage thousands more to set out for the New World to make their fortunes.

By the end of the 1530s the more far-sighted settlers were turning from the simple looting of a diminishing stock of native gold objects to mining. Both Peru and, to a lesser degree, Mexico were to become significant gold-producers by the middle of the sixteenth century, as were Chile and New Granada (modern Colombia). But, following the discovery of fabulously rich silver deposits at Potosí (in modern Bolivia) in 1545 and at Zacatecas (Mexico) in 1548, it became clear that silver mining was to become the basis of economic life in Spanish America. The relative importance of the two metals is starkly indicated by the estimate that between 1500 and 1650 registered trade alone conveyed 181 tons of gold and 16,000 tons of silver to Spain from her American colonies.

Because of its greater value and its legendary appeal, however, gold-or, to be more precise, the quest for gold-continued for many more decades to draw Spaniards deeper into the Americas. Much of the present-day territory of the United States South-west and South-east was traversed in 1540-43 by the expeditions of Hernando de Soto and Francisco Vázquez de Coronado as they searched for the metal. Coronado penetrated as far as eastern Kansas before finally accepting that the legendary Seven Cities of Cíbola were merely the humble dwellings of the Pueblo Indians, and Soto's exploration of Florida as far north as the Savannah River also proved fruitless. Thereafter, although retaining Florida for strategic reasons, Spain left the rest of the eastern seaboard of

The form in which gold from the Americas was shipped to Spain. This large dise shows the circular Royal Seals which were stamped after the Royal Fifth had been paid, the reetangular mark with six letters denoting the place where it was cast, and, in Roman numerals, the gold content of the alloy in quilates (carats) and granos (grains). This disc, only $15^{3}$ carats fine, was recently recovered from the wreck of a Spanish Galleon, Nuestra Señora de Atocha, which sank in a hurricane off Florida in 1622

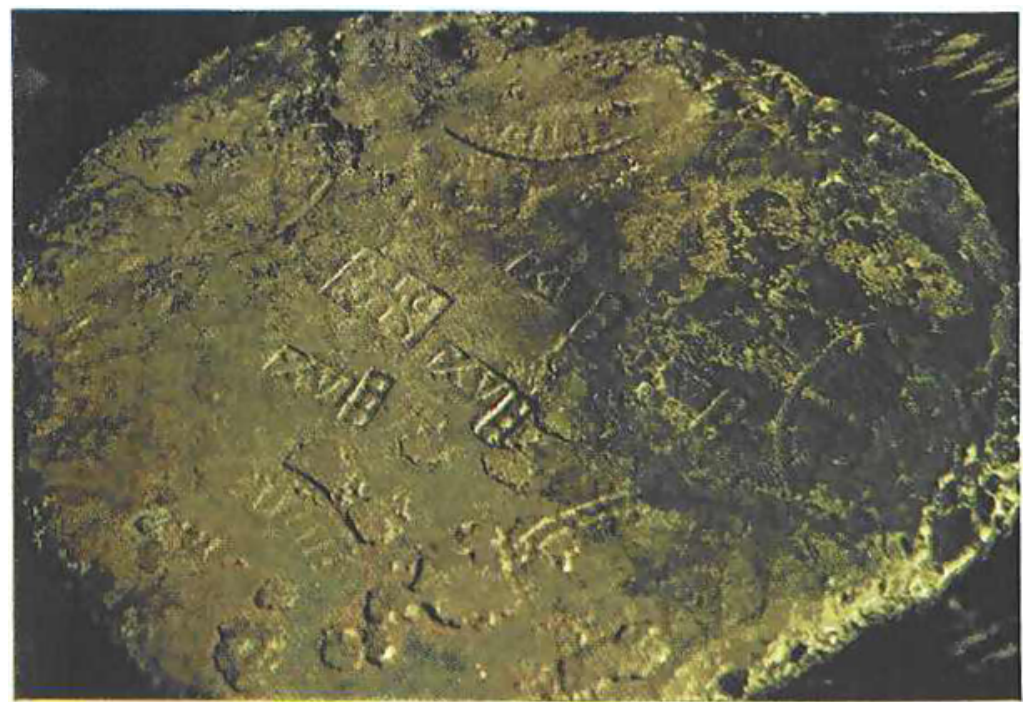




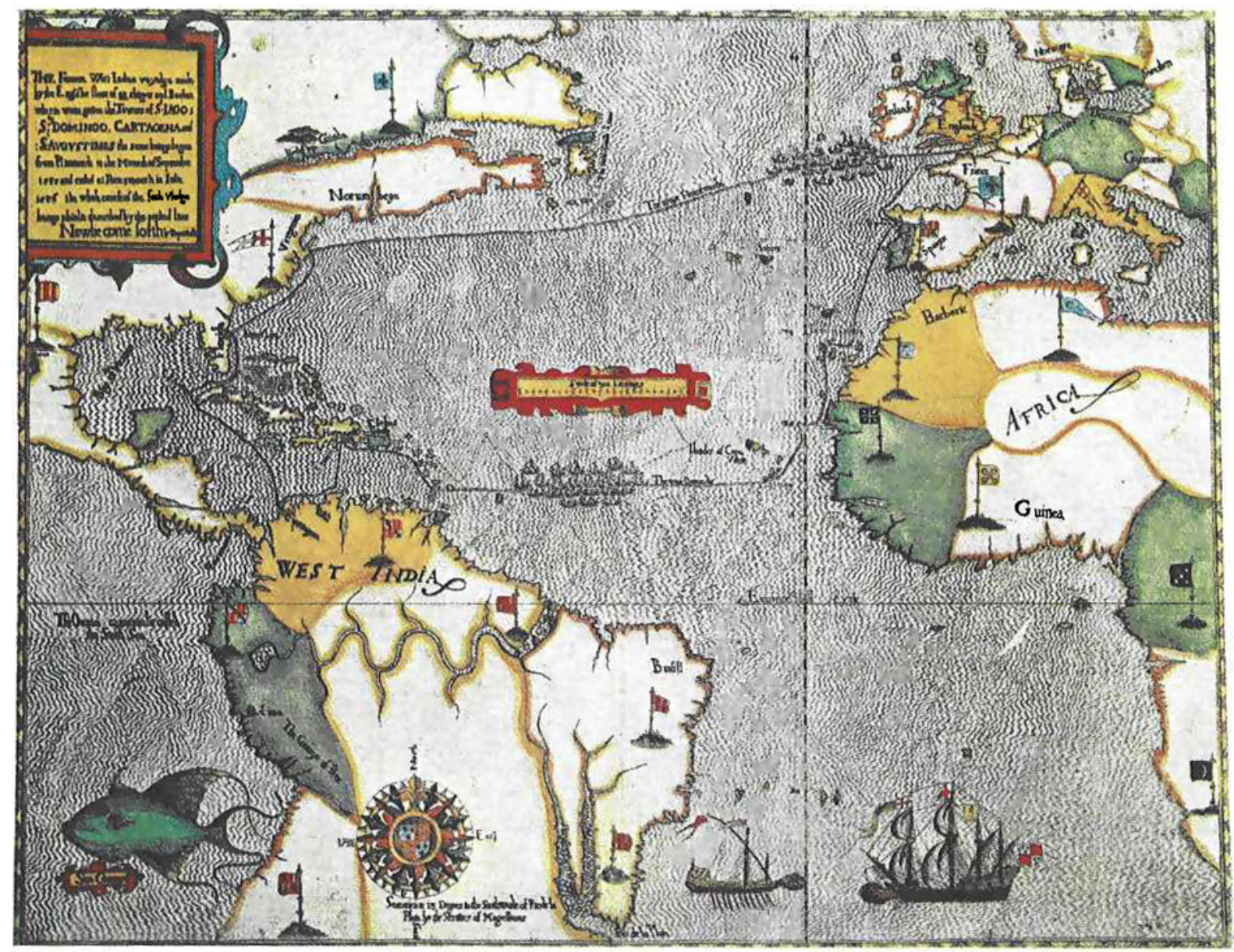

A track chart of the Atlantic Ocean prepared in 1588 by Baptista Bragio, an Italian cartographer living in London, from information given to him by Francis Drake after his raid on the Spanish Indies. It also records Drake's visit to Roanoke, off the coast of what is now North Carolina, to take off Raleigh's colonists and bring them back to England after their unsuccessful search for gold in the island Courtesy of the Paul Mellon Collection, Upperville, Virginia

North America to the attention of other nations.

The challenge was taken up primarily by England, and there is abundant evidence that the hope of finding gold was one of the main considerations that lay behind the increasing involvement of Elizabethan explorers and adventurers with the new continent. The significance which Elizabeth I and her ministers attached to mining and national self-sufficiency in both precious and base metals was evident from the very beginning of her reign, when German technologists, brought into the country originally to refine its base coinage, were encouraged to prospect for minerals in England itself. Daniel Höchstetter, a master miner and refiner from Augsburg, and Thomas Thurland, an Englishman, found rich copper ore containing silver at Keswick, in Cumberland, in 1564-5. The outcome was the incorporation in 1568 of the famous Company of the Mines Royal to exploit domestic mineral resources. Although a majority of its shareholders were English, control of the mining and refining operations was in the hands of German specialists led by Höchstetter. Cumber- land remained the centre of operations, but mines were also opened in Wales and Cornwall, and a Dutch shareholder, Cornelius de Vos, was involved in gold mining at Crawford Moor on the River Clyde in Scotland.

It was generally recognised, however, that the prospects of large-scale gold production at home were remote. America, on the other hand, seemed to offer a much more attractive prospect, particularly since the expertise of the Germans might be used to advantage there. The first significant involvement arose out of the voyage which Martin Frobisher made in 1576 in search of a Northwest Passage to Asia (and its gold), for he returned to England from Baffin Island with samples of a glittering black rock, probably marcasite, which he believed to be gold ore. The German scientist Burchard Kranisch, who earlier in his career had smelted lead in Derbyshire and silver in Cornwall, confirmed this opinion. It seems that for reasons which are unclear he "salted" melts of the ore with gold and silver coins of the realm. Frobisher brought back no less than two 
hundred tons of "ore" from a second voyage in 1577 . It was only when he returned home a third time from a major expedition carrying Cornish miners that he discovered his error.

The powerful clique of adventurers and entrepreneurs, led by Richard Hakluyt and Sir Humphrey Gilbert, which was emerging in London to promote schemes for English colonisation in North America, was not deterred by this setback. Gilbert himself sailed in June 1583 to explore the southern shores of New England with a party which included, according to the narrative of Edward Hayes, "the minerall man and refiner .... a Saxon borne, honest and religious, named Daniel"'. They went first to Newfoundland, which Gilbert formally annexed, and there Daniel, Hayes tells us:

"after search brought at first some sort of Ore, seeming rather to be yron then other metall. The next time he found Ore, which with no small shew of contentment he delivered unto the General, using protestation, that if silver were the thing which might satisfie the Generall \& his followers, there it was, advising him to seek no further."

Shortly afterwards "our Saxon refiner and Discoverer of inestimable riches" and his ore were lost in a shipwreck-Gilbert, too, perished later on the voyageand, despite the efforts of Hayes, plans for the settlement of Newfoundland and New England were deferred in favour of attempts further south, in Virginia.

Sir Walter Raleigh, like his half-brother Gilbert, whose patent he took over after the latter's death, clearly hoped to find gold in North America. Anonymous notes written for his guidance as he prepared for the expedition which was to found the first settlement on Roanoke Island in 1585 advised him:

"An alcamist is not Impertinent, to trye the metaylls that maybe discouerd and ... sum of $\mathrm{y}^{\mathrm{e}}$ myners of Cornwell ..."

We know that this advice was heeded, for various accounts of the colony refer to the presence of a mineralogist who was clearly Joachim Gans, a Jew, born in Prague, who had produced an outstanding technical report on smelting techniques for the Company of the Mines Royal at Keswick in 1581. Richard Hakluyt's list of colonists, published in 1589 calls him "Doughan Gannes"-it also has another "Daniel", who, it has been suggested, could have been Daniel Höchstetter-while the report of Ralph Lane, who was left in charge of the enterprise by Raleigh, refers to him as "Master Yougham". Lane describes the search for gold in some detail, telling us:

"And touching the Minerall, thus doth Master Yougham affirme, that though it be but copper, seeing the Sauages are able to melt it, it is one of the richest Minerals in the worlde."
Copper, no matter how pure, was no substitute, of course, for gold. Nor was the iron of which Thomas Hariot, another participant, wrote in 1588:

"... we found neere the water side the grounde to be rockie, which by the triall of a minerall man, was found to hold yron richly."

The same commentator also reported finds of silver"... we founde ... Riuers that yeelde also whyte graynes of Metall, which is to be deemed Siluer"which was more promising, but gold remained the principal objective. Despite his inevitable disappointment at the failure of the Roanoke colonythe settlement was abandoned in July 1586-Raleigh continued to hope for precious metals in Virginia. He took care in 1589, for example, to reserve for himself, in an agreement drawn up with various merchants for fresh settlement:

"the fift part of all the oare of golde, and siluer that from time to time, and at all times after such discouerie ... shalbe there gotten and obtained..."

In fact, the last decade of the sixteenth century saw no further English settlement in North America, as, following the attack by the Armada, energies and resources were diverted to fighting Spanish shipsand seizing their treasure-on the high seas. It was not until 1607 that the Jamestown colony, the first permanent English settlement, was established by the Virginia Company. Although its promoters and the settlers continued to hope for gold-John Smith protested that there was "no talke, no hope, nor worke, but dig gold, refine gold, load gold"-the metal simply did not materialise. The colony survived, however, for by 1614 its economic salvation had arrived in a different guise, following the introduction of tobacco from Trinidad. By the end of the decade 50,000 pounds of tobacco were being shipped to England each year for sale at high prices.

By the second half of the seventeenth century the English settlers in both Virginia and New England had reconciled themselves to making their fortunes from agriculture and trade rather than mining. For the individual and the nation the ultimate objective remained the possession of gold, but, as Richard Hakluyt had foreseen, it was to be obtained not from mining, as in Spanish America, but from the sale of agricultural produce and manufactured goods on the world market. For the North American Indians this latter course was to prove even more destructive than the Spanish preoccupation with mining, for they had to be driven from their land to release it for farming. Roger Williams, the founder of Rhode Island, anticipated this development with his shrewd observation:

"That God Land will be as great a God with us English as God Gold was with the Spaniard." 